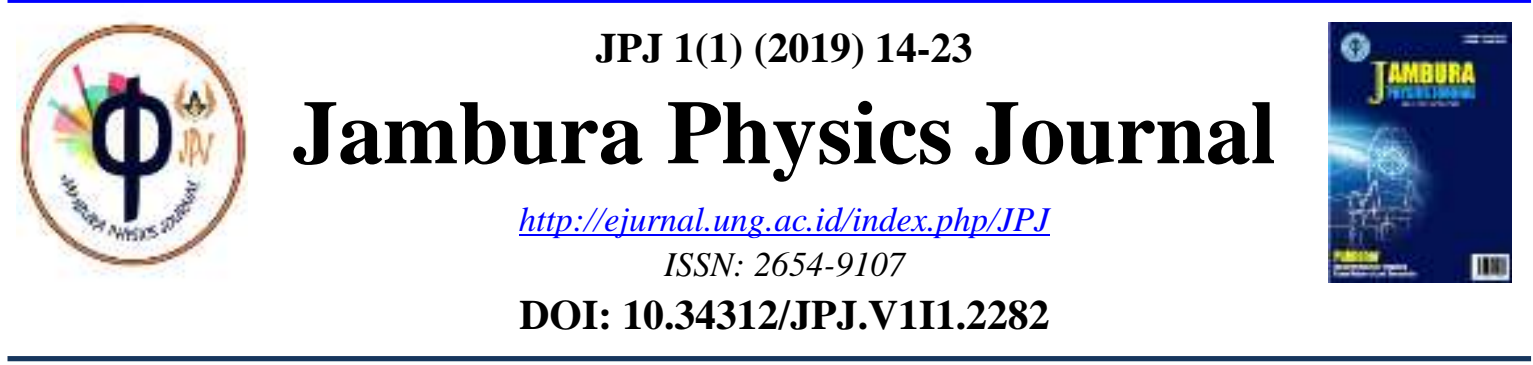

\section{IMPLIKASI MODUL PEMBELAJARAN PREDICT-OBSERVE- EXPLAIN KAJIAN SUHU DAN KALOR TERHADAP HASIL BELAJAR PESERTA DIDIK}

\author{
Pakaya. R. P( ${ }^{1^{*}}$,Mursalin ${ }^{2}$ \\ ${ }^{1}$ Dinas Pendidikan dan Kebudayaan, Gorontalo Utara \\ ${ }^{2}$ Pendidikan Fisika UNG, Gorontalo
}

Accepted: December 20 2018. Approved: April 03 2019. Published: April 292019

\begin{abstract}
Abstrak
Pengorganisasian dan penyampaian isi bahan ajar dalam bentuk buku tidak terstuktur dengan baik serta materi pembelajaran banyak yang bersifat abstrak dan rumit yang menyebabkan peserta didik malas untuk membaca apalagi mempelajarinya. Bahan ajar yang cukup efektif untuk meningkatkan hasil belajar adalah modul. Penelitian ini memaparkan hasil penerapan modul pembelajaran Predict-Observe-Explain (POE) pada topik suhu dan kalor. Penelitian menggunakan metode kuasi eksperimen dengan rancangan One Group Pretest-Posttest Design.

Pengambilan sampel dilakukan dengan teknik cluster random sampling. Instrumen penelitian yang digunakan adalah tes uraian tertulis, lembar aktivitas peserta didik, dan angket. Analisis data dilakukan dengan menggunakan rerata gain ternormalisasi dan presentase. Hasil penelitian mengungkapkan bahwa penerapan modul pembelajaran $P O E$ pada topik suhu dan kalor dapat meningkatkan hasil belajar kognitif peserta didik yakni nilai gain 0.85 (kategori tinggi). Data pendukung dari penelitian ini adalah rerata persentase aktivitas belajar peserta didik dalam mempelajari fisika topik suhu dan kalor menunjukan kategori sangat baik, sementara respon peserta didik terhadap penerapan modul pembelajaran $P O E$ adalah positif. Secara keseluruhan modul pembelajaran $P O E$ pada topik suhu dan kalor terbukti praktis dan efektif untuk digunakan.
\end{abstract}

Kata Kunci: Modul Pembelajaran; model $P O E$; fisika

\footnotetext{
*Alamat Korespondensi

E-mail: : relinpandalisp@gmail.com
} 


\section{Pendahuluan}

Belajar pada hakikatnya adalah proses interaksi antara individu dengan lingkungannya yang diarahkan pada tujuan dan perbuatan melalui berbagai pengalaman (Rusman, 2012: 1). Pembelajaran pada prosesnya memerlukan peran guru yang tidak hanya sebagai model atau teladan bagi peserta didik namun sebagai pengelola pembelajaran (manager of learning) sehingga efektivitas proses pembelajaran yang ditandai dengan keberhasilan suatu proses pembelajaran terletak pada peran seorang guru (Rohman \& Amri, 2013: 4). Sejalan dengan pernyataan ini, Syah dalam Suprihatiningrum (2013: 109) mengatakan bahwa keberhasilan dalam pembelajaran bergantung pada bagaimana guru merencanakan pembelajarannya. Perencanaan pembelajaran diartikan sebagai proses penyusunan materi pembelajaran, penggunaan media, pendekatan dan metode serta penilaian dalam mencapai tujuan pembelajaran. Perencanaan proses pembelajaran dan persiapan guru akan menentukan besarnya ketercapaian tujuan pembelajaran (Yusuf, 2011).

Salah satu media, bahan ajar dan sumber belajar yang membantu guru maupun peserta didik dalam proses pembelajaran adalah buku.Berdasarkan analisis kebutuhan yang dilakukan dalam penelitian Aprianti, dkk (2015: 138) dengan 13 guru bidang studi fisika didapatkan bahwa semua sekolah menggunakan buku paket sebagai bahan ajar. Ada 10 sekolah yang melengkapi buku paket dengan LKS yang memuat materi, contoh soal dan latihan yang dibeli dari penerbit buku tertentu. Strategi pengorganisasian dan penyampaian isi dalam bahan ajar tersebut tidak terstruktur dengan baik serta materi pembelajaran banyak yang bersifat abstrak dan rumit yang menyebabkan peserta didik malas untuk membaca apalagi mempelajarinya.Bentuk bahan ajar yang dipilih oleh 11 guru dan 28 peserta didik adalah bahan ajar cetak. Bahan ajar cetak yang cukup efektif untuk meningkatkan hasil belajar adalah modul.

Berdasarkan hasil tersebut maka penulis tergugah untuk menerapkan modul pembelajaran fisika yang diintegrasikan dengan salah satu model pembelajaran. Salah satu model pembelajaran yang memungkinkan peserta didik yang menggunakan modul adalah model POE. Model pembelajaran POE menurut Wahyuni, dkk (2013: 270) merupakan salah satu model pembelajaran yang dikembangkan untuk mengetahui kemampuan peserta didik dalam memprediksi suatu fenomena alam serta alasannya. Model pembelajaran ini menggunakan beberapa metode saintifik yakni memprediksi atau berhipotesis (predict), melakukan pengamatan terkait hipotesisnya (observe) dan menganalisis kesesuaian hipotesis dengan hasil pengamatan (explain). Penelitian yang dilakukan oleh Nuraini, dkk (2014) menyatakan bahwa modul berbasis $P O E$ dapat menjadikan siswa lebih aktif selama 
pembelajaran dan terbukti efektif dalam memberdayakan keterampilan proses sains dan kemampuan menjelaskan siswa.

Berdasarkan hasil analisis terkait penggunaan modul dan model pembelajaran POE serta manfaatnya, maka penulis tergugah untuk menerapkan modul pembelajaran berbasis POE(Predict-Observe-Explain)pada topik suhu dan kalor di kelas X.

\section{Masalah Penelitian.}

Rumusan masalah pada penelitian ini adalah bagaimanakah implikasi modul pembelajaran POE pada materi suhu dan kalor.

\section{Fokus penelitian}

Penelitian dilaksanakan pada siswa SMA kelas X dan difokuskan pada pelajaran Fisika materi suhu dan kalor.

\section{Kajian Pustaka}

\section{Modul}

Modul merupakan salah satu bahan, media, dan sumber belajar yang dapat digunakan dalam pembelajaran. Modul menurut Solong (2008:119) adalah suatu unit bahan yang dirancang oleh pengajar secara khusus, utuh, sistematis dan mengacu pada tujuan pembelajaran yang jelas dan dapat diukur untuk dipelajari oleh peserta didik secara mandiri.Modul memuat tujuan pembelajaran, bahan dan kegiatan serta evaluasi terhadap hasil pencapaian peserta didik.

Mulyasa dalam Solong (2008: 121-124)mengemukakan belajar dengan sistem modul memiliki karakteristik sebagai berikut.

a. Memberikan informasi yang jelas terkait dengan petunjuk pelaksanaan yang jelas untuk dilakukan oleh peserta didik dan pemilihan sumber belajar yang harus digunakan.

b. Melibatkan sebanyak mungkin karakteristik peserta didik sehingga setiap modul harus memungkinkan peserta didik mengalami kemajuan baik dengan kemampuannya sendiri maupun dari hasil belajar yang sebelumnya telah diperoleh serta memfokuskan peserta didik pada tujuan pembelajaran yang spesifik dan dapat diukur.

c. Membantu peserta didik mencapai tujuan pembelajaran dari pengalaman belajar yang aktif, tidak hanya membaca dan mendengar melainkan memberi kesempatan untuk bermain peran, simulasi dan berdiskusi. Bentuk Aktivitas belajar yang dirangkum dalam modul menurut Diknas dalam Solong (2008:124) setidaknya memuat 3 aktivitas 
yaitu aktivitas mental atau pikiran, aktivitas membaca atau menulis dan aktivitas melakukan tindakan lain misalnya praktikum, observasi, demonstrasi dan tugas pekerjaan rumah.

d. Memudahkan peserta didik untuk mengetahui kapan dia akan memulai dan mengakhiri suatu modul tanpa menimbulkan pertanyaan apa yang harus dilakukan atau dipelajari karena materi pembelajaran disajikan secara logis dan sistematis.

e. Memiliki mekanisme untuk mengukur pencapaian tujuan belajar peserta didik terutama untuk memberi refleksi bagi peserta didik dalam mencapai ketuntasan belajar. Hal ini menjadi suatu kriteria atau standar kelengkapan modul.

Penggunaan modul dalam pembelajaran didukung oleh teori belajar konstruktivisme. Menurut Sardiman (2014: 37-38) teori ini memandang bahwa belajar merupakan proses aktif dari peserta didik untuk merekonstruksi makna baik itu teks, kegiatan dialog, pengalaman fisik dan lain-lain. Aunurrahman (2012: 18-19) menyatakan bahwa belajar dalam pandangan konstruktivisme merupakan kegiatan aktif peserta didik dalam menemukan pengetahuan, konsep, kesimpulan dan bukan merupakan kegiatan mekanistik untuk mengumpulkan informasi atau fakta. Pandangan belajar yang seperti ini hampir menyerupai karakteristik belajar dengan menggunakan modul yang telah dibahas sebelumnya.

\section{Model POE}

POE pertama kali diperkenalkan oleh White dan Gunstone pada tahun 1995 dalam bukunya yang berjudul Probing Understanding.Model POEmenurut Liew \& Treagust (1998: 2) merupakan model pembelajaran yang berimplikasi terhadap hasil belajar peserta didik dari pandangan konstruktivis. Konstruktivisme merupakan suatu pandangan dalam pembelajaran yang beranggapan bahwa untuk memahami teori dan memperoleh pengetahuannya siswa harus aktif membangun pengetahuannya sendiri, guru tidaklah berperan sebagai pentransfer informasi tetapi sebagai fasilitator dalam proses pembelajaran yang membantu siswa untuk membangun pengetahuannya.

Model POEmemiliki sintaks yang terdiri atas prediksi, observasi danmenjelaskan, sehingga dengan menerapkan model iniselama pembelajaran peserta didik dapat aktif berpikir danmengembangkan keterampilan proses sains yang meliputi memprediksi,mengamati dan menjelaskan. Beberapa penelitian jugatelah membuktikan bahwa model POE ini mampumembantu peserta didik lebih aktif selama proses pembelajaranterutama dalam membuktikan suatu konsep berdasarkanhasil pengamatan dan 
analisis yang mereka lakukansendiri. Peserta didik juga menjadi lebih tertantang untukmembuktikan hasil prediksi mereka melalui serangkaiankegiatan percobaan atau observasi(Nuraini, dkk, 2014: 38).

Tabel 1. Sintaks Model $P O E$ menurut Liew dan David

\begin{tabular}{ll}
\hline $\begin{array}{l}\text { Langkah } \\
\text { Pembelajaran }\end{array}$ & Aktivitas Peserta Didik \\
\hline Tahap 1 & Memberikan hipotesis berdasarkan permasalahan yang diambil dari \\
Predict & pengalaman peserta didik itu sendiri atau dari buku panduan yang memuat \\
Meramalkan & suatu fenomena terkait materi yang akan dibahas. \\
Tahap 2 & Mengobservasi dengan melakukan eksperimen atau demonstrasi berdasarkan \\
Observe & permasalahan yang dikaji dan mencatat hasil pengamatan untuk direfleksikan \\
Mengamati & satu sama lain. \\
Tahap 3 & Mendiskusikan fenomena yang telah diamati dan membandingkan hasil \\
Explain & observasi dengan hipotesis sebelumnya bersama kelompok masing-masing. \\
Menjelaskan & Mempresentasikan hasil observasi di kelas, serta kelompok lain memberikan \\
& tanggapan sehingga diperoleh kesimpulan dari permasalahan yang sedang \\
\hline
\end{tabular}

(Liew \& Treagust, 1998: 5-6)

\section{Hasil Belajar}

Miarso (dalam Uno, 2013: 173) memandang bahwa Suatu proses belajar mengajar dapat dikatakan berhasil baik, jika kegiatan belajar mengajar tersebut dapat membangkitkan proses belajar. Penentuan atau ukuran pembelajaran yang efektif terletak pada hasilnya. Menurut Hakim, dkk (2015:767) keefektifan suatu pembelajaran dapat dilihat berdasarkan hasil belajar dan respon peserta didik.

Terdapat 3 macam hasil belajar menurut Anderson dan Krathwohl(2010: 95-102)yakni: 1) hasil belajar yang tidak ada karena tidak ada aktivitas belajar baik memperhatikan maupun memahami materi yang diajarkan, 2) hasil belajar menghafal dengan menyimak informasi yang relevan namun tidak memahaminya, dan 3) hasil belajar bermakna yang bukan hanya mengetahui pengetahuan yang relevan namun dapat menggunakannya dalam menyelesaikan masalah dan memahami konsep-konsep baru.Asesmen dalam mengukur hasil belajar bermakna mengacu pada dimensi proses kognitif.

Hasil belajar dipengaruhi oleh motivasi peserta didik untuk belajar. Perlunya memotivasi diri dan menumbuhkan minat belajar dalam diri peserta didik menjadi ciri dari prestasi individu (Eggen \& Kauchak, 2012: 97). Motivasi dan minat belajar merupakan faktor internal dalam upaya meningkatkan hasil belajar. Menurut Sardiman (2014: 73-74) motivasi berasal dari kata motif dan dapat dikatakan sebagai daya penggerak yang telah menjadi aktif. Motif menjadi aktif pada saat tertentu, khususnya saat desakan atau saat merasakan pentingnya mencapai tujuan tertentu. 


\section{Metodologi Penelitian}

\section{Metode Penelitian}

Penelitian ini merupakan penelitian eksperimen semu atau quasi experiment dengan desain one group pretest-posttest.

\section{Sampel Penelitian}

Populasi penelitian ini adalah peserta didik kelas X suatu MA di Kabupaten Gorontalo Utara tahun pelajaran 2017/2018. Pengambilan sampel dilakukan dengan teknik cluster random sampling.

\section{Instrumen dan Prosedur}

Metode yang dilakukan adalah tes, observasi dan angket. Instrumen pengumpulan data yang digunakan adalah tes uraian tertulis,lembar aktivitas peserta didikdan angket.

Data yang dikumpulkan dalam penelitian ini adalah hasil belajar kognitif, aktivitas pembelajaran dan respon peserta didik. Hasil belajar kognitif peserta didik diukur dengan menggunakan tes, sementara aktivitas peserta didik diukur dengan persentase observasi aktivitas peserta didik dan respon peserta didik diukur dengan menggunakan angket.

Tes dilakukan sebelum dan sesudah pembelajaran menggunakan modul model POE untuk melihat ada tidaknya peningkatan pengetahuan kognitif peserta didik.

\section{Analisis Data}

Peningkatan kemampuan ini dapat di analisis dengan rumus Hake Hake (Mursalin, 2014: 96):

$$
\mathrm{N}-\mathrm{Gain}=\frac{\mathrm{S}_{\text {posr }} \mathrm{S}_{\text {pre }}}{\mathrm{S}_{\mathrm{Nax}}-\mathrm{S}_{\text {pre }}}
$$

Keterangan : $S_{\text {poss }}=$ rata-rata nilai post tes

$$
\mathrm{S}_{\mathrm{pre}}=\text { rata-rata nilai pre tes }
$$$$
\mathrm{S}_{\mathrm{Max}}=\text { Skor Maksimal }
$$

Besarnya faktor gain dikategorikan dalam Tabel 2.

Tabel 2Kategori Nilai Gain Ternormalisasi

\begin{tabular}{cc}
\hline Nilai Gain & Kategori \\
\hline $\mathrm{g}>0,7$ & Tinggi \\
$0,3<\mathrm{g} \leq 0,7$ & Sedang \\
$\mathrm{g} \leq 0,3$ & Rendah
\end{tabular}


Pengamatan aktivitas peserta dilakukan untuk mengetahui persentase keaktifan peserta didik dihitung dengan menggunakan rumus:

$$
\% \text { keaktifan }=\frac{\text { Jumlah Skor Indikator }}{\text { Skor Maksimal }} \times 100
$$

Kategori persentase keaktifan peserta didik Menurut Purwanto (dalam Nurhayati, 2013: 6)disajikan dalam Tabel 3.

Tabel 3 Kategori persentase keaktifan peserta didik

\begin{aligned} \hline Persentase Keaktifan $(\%) &$ Kategori \\ \hline Skor $\geq 85 \% &$ Sangat Baik \\ $85 \%>$ Skor $\geq 70 \% &$ Baik \\ $70 \%>$ Skor $\geq 55 \% &$ Kurang Baik \\ Skor $<55 \% &$ Tidak Baik \end{aligned}

Angket dilakukan untuk mengetahui respon peserta didik terhadap penerapan modul model $P O E$ dalam pembelajaran. Kegiatan ini dilakukan setelah pembelajaran dengan menyajikan angket tertutup dalam bentuk sedemikian rupa sehinggapeserta didik dapat memberikan respon terhadap penggunaan modul model $P O E$.

Data respon peserta didik dari pengisian angket tertutup dianalisis dengan berdasarkan pada rata-rata kelas $(\bar{x})$ dari respon peserta didik, $M i$, SDi. Rata-rata kelas dari skor respon peserta didik menurut Nurkancana dan Sunarta dalam Priatna, dkk (2017: 74)dihitung dengan rumus.

$$
\overline{\mathrm{x}}=\frac{\sum \mathrm{x}}{\mathbb{N}}
$$

Keterangan: $\overline{\mathrm{x}}=$ Rata-rata kelas untuk skor respon peserta didik

$\sum \mathrm{x}=$ Jumlah skor respon peserta didik

$\mathrm{N}$ = Banyaknya peserta didik

Kriteria penggolongan respon menurut Priatna, dkk (2017:74) dapat dilihat pada Tabel 4.

Tabel 4 Kriteria Penggolongan Respon

\begin{tabular}{ll}
\hline Interval & Kategori \\
\hline $\mathrm{Mi}+1.5 \mathrm{SDi} \leq \overline{\mathrm{x}}$ & Sangat Positif \\
$\mathrm{Mi}+0.5 \mathrm{SDi} \leq \bar{x}<\mathrm{Mi}+1.5 \mathrm{SDi}$ & Positif \\
$\mathrm{Mi}-0.5 \mathrm{SDi} \leq \bar{x}<\mathrm{Mi}+0.5 \mathrm{SDi}$ & Kurang Positif \\
$\mathrm{Mi}-1.5 \mathrm{SDi} \leq \bar{x}<\mathrm{Mi}-1.5 \mathrm{SDi}$ & Negatif \\
$\bar{x}<\mathrm{Mi}-1.5 \mathrm{Sdi}$ & Sangat Negatif
\end{tabular}

Meanideal $(M i)$ dan standar deviasi ideal (SDi) diperoleh dengan menggunakan rumus. 


$$
\begin{aligned}
& \mathrm{Mi}=\frac{1}{2}(\text { skor maksimal }+ \text { skor minimal }) \\
& \mathrm{SDi}=\frac{1}{6}(\text { skor tertinggi }+ \text { skor minimal })
\end{aligned}
$$

\section{Hasil dan Pembahasan}

Implikasi penerapan modul model $P O E$ materi suhu dan kalor dapat dilihat dari hasil belajar, keaktifan dan respon peserta didik itu sendiri sebagaimana hasil dari beberapa penelitian terdahulu.Penggunaan modul dapat meningkatkan hasil belajar. Peningkatan hasil belajar dapat diketahui dengan memberikan pre-post test kepada peserta didik. Ratarata hasil belajar kognitif peserta didik pada materi suhu dan kalor sebelum menggunakan modul adalah 23 dan setelah menggunakan modul adalah 89, sehingga peningkatan hasil belajar adalah 0.86. Angka ini menunjukan bahwa peningkatan hasil belajar peserta didik pada materi suhu dan kalor berada pada kategori tinggi.

Data pendukung dari penelitian ini adalah persentase keaktifan peserta didik dalam pembelajaran diperoleh dari hasil pengamatan seorang observer. Hasil pengamatan tersebut dapat dilihat pada Tabel 5.

Tabel 5 Hasil pengamatan aktivitas 26 peserta didik

\begin{tabular}{llccccc}
\hline No & $\begin{array}{c}\text { Aktivitas Peserta } \\
\text { didik }\end{array}$ & $\mathbf{1}$ & $\mathbf{2}$ & $\mathbf{3}$ & $\mathbf{4}$ & Rerata (\%) \\
& \multicolumn{1}{c}{ Pertemuan (\%) } \\
\hline 1 & Predict & 100 & 100 & 100 & 100 & 100 \\
2 & Observe & 94 & 94 & 94 & 96 & 95 \\
3 & Explain & 88 & 88 & 92 & 92 & 90
\end{tabular}

Berdasarkan data di atas terlihat bahwa kategori keaktifan peserta didik sangat baik. Hal ini menginterpretasikan bahwa penerapan modul model $P O E$ dapat mengaktifkan peserta didik untuk belajar.Hasil observasi persentase keaktifan peserta didik menunjukan kategori sangat baik. Hal ini sesuai dengan kategori keaktifan yang dinyatakan oleh Purwanto yakni peserta didik dikatakan aktif dengan kategori sangat baik jika persentase keaktifan mencapai lebih dari sama dengan $85 \%$.

Selain aktivitas peserta didik, kepraktisan suatu modul dilihat dari respon peserta didik dari pengisian angket. Pengisian angketdari 26 orang peserta didik menghasilkan jumlah respon tertinggi peserta didik sebesar 109, sedangkan skor maksimal dari respon adalah 150 dan skor minimalnya adalah 30. Berdasarkan nilai inilah, peneliti menghitung hasil respon peserta didik. Rata-rata respon peserta didik $\bar{x}$ yang dihitung menggunakan persamaan (3) adalah 105. Rentang dan penggolongan nilai respon peneliti menggunakan 
persamaan (4) dan (5) yang menghasilkan nilai Mi sebesar 90 dan SDi sebesar 23. Nilai tersebut disubtitusi dan dioperasikan sesuai dengan yang ada pada Tabel 2 sehingga rentang dan penggolongan nilai respon peserta didik dapat pada Tabel 6.

Tabel 6 Kriteria Penggolongan Respon 26 Peserta Didik

\begin{tabular}{ll}
\hline Interval & Kategori \\
\hline $125 \leq \overline{\mathrm{x}}$ & Sangat Positif \\
$102 \leq \bar{x}<125$ & Positif \\
$78 \leq \bar{x}<102$ & Kurang Positif \\
$55 \leq \bar{x}<78$ & Negatif \\
$\bar{x}<55$ & Sangat Negatif
\end{tabular}

Hasil dari rata-rata respon peserta didik dan pencocokan kriteria penggolongan respon menunjukan bahwa penggunaan modul pembelajaran dengan modul POE mendapatkan respon positif.

\section{Kesimpulan}

Berdasarkan hasil penelitian dan pembahasan diperoleh bahwa penerapan modul pembelajaran model $P O E$ pada materi suhu dan kalor dapat meningkat hasil belajar peserta didik dengan nilai gain 0.86 berkategori tinggi. Selain itu, penerapan modul ini juga dapat mengaktifkan peserta didik dalam belajar fisika bukan hanya membaca dan menulis namun lebih kepada aktivitas memprediksi, mencoba dan menjelaskan. Hal ini dibuktikan dengan persentase aktivitas prediksi adalah 100\%, aktivitas observasi dengan persentase $95 \%$ dan menjelaskan sebesar 90\%. Data pendukung dalam penerapan modul pembelajaran fisika model $P O E$ berupa hasil pengisian angket yang menyatakan bahwa rata-rata respon peserta didik terhadap penggunaan modul pembelajaran $P O E$ pada materi suhu dan kalor adalah positif. Secara keseluruhan, ketiga hasil penelitian tersebut mengindikasikan bahwa penerapan modul model $P O E$ pada materi suhu dan kalor dapat meningkatkan hasil belajar kognitif, mengaktifkan kegiatan belajar dan mendapatkan respon positifdari peserta didik.

\section{Referensi}

Anderson, L. W., \& Krathwohl, D. R. (2010). Kerangka Landasan untuk Pembelajaran, Pengajaran da Asesmen Revisi Taksonomi Pendidikan Bloom. Yogyakarta: Pustaka Pelajar.

Aprianti, R., Desnita, \& Budi, E. (2015). Pengembangan Modul Berbasis Contextual Teaching and Learning (CTL) dilengkapi dengan Media Audio-Visual untuk Meningkatkan Hasil Belajar Fisika Peserta Didik SMA. Prosiding Seminar Nasional Fisika (E-Journal) SNF2015, IV, 137-142.

Aunurrahman. (2012). Belajar dan Pembelajaran. Bandung: Alfabeta. 
Eggen, P., \& Kauchak, D. (2012). Strategi dan Model Pembelajaran. Jakarta: Indeks.

Hakim, M. L., Prabowo, \& Yuanita, L. (2015). Pengembangan Perangkat Pembelajaran Fisika Model Inkuiri Terbimbing sebagai Upaya Meningkatkan Hasil Belajar Siswa pada Materi Kalor di SMA. Pendidikan Sains Pascasarjana Universitas Negeri Surabaya, 764-768.

Liew, C. W., \& Treagust, D. F. (1998). The Effectiveness ofPredict-Observe-Explain Tasks in DiagnosingStudents' Understanding of Science and inIdentifying their levels ofAchievement. Educational Resources Information Center (ERIC), 2-22.

Mursalin. (2014). Meminimalkan Miskonsepsi Materi Rangkaian Listrik dengan Pembelajaran Predict-Observe-Explain. Jurnal Ilmu Pendidikan, 94-99.

Nuraini, N., Karyanto, P., \& Sudarisman, S. (2014). Pengembangan Modul Berbasis POE (Predict, Observe and Explain) disertai Roundhouse Diagram untuk Memberdayakan Keterampilan Proses Sains dan Kemampuan Menjelaskan SIswa Kelas X SMA Negeri 5 Surakarta. Bioedukasi, 37-43.

Priatna, I. K., Putrama, I. M., \& Divayana, D. G. (2017). Pengembangan E-Modul Berbasis Model Pembelajaran Project Based Learning pada Mata Pelajaran Videografi untuk Siswa Kelas X Desain Komunikasi Visual di SMA Negeri 1 Sukasada. Jurnal Nasional Pendidikan Teknik Informatika, 70-78.

Purwanto, Rahadi, A., \& Lasmono, S. (2007). Pengembangan Modul. Jakarta: PUSTEKKOM Depdiknas.

Rohman, \& Amri. (2013). Strategi \& Desain Pengembangan Sistem Pembelajaran. Jakarta: Prestasi Pustaka.

Rusman. (2012). Model-model Pembelajaran. Jakarta: PT Raja Grafindo Persada.

Sardiman. (2014). Interaksi dan Motivasi Belajar Mengajar. Jakarta: RajaGrafindo Persada.

Solong, N. P. (2008). Pengembangan Materi PAI. Gorontalo: Sultan Amai Press.

Suprihatiningrum, J. (2013). Strategi Pembelajaran. Jogjakarta: Ar-Ruzz.

Uno, H. (2013). Belajar dengan Pendekatan Pembelajaran Aktif Inovatif Lingkungan Kreatif Efektif Menarik. Jakarta: Bumi Aksara.

Wahyuni, S. E., Sudarisman, S., \& Karyanto, P. (2013). Pembelajaran Biologi Model POE (Prediction, Observation, Explanation) melalui Laboratorium Riil dan Laboratorium Virtuil ditinjau dari AKtivitas Belajar dan Kemampuan Berpikir Abstrak. JURNAL INKUIRI , 269-278.

Yusuf, M. 2011. Peningkatan Kemampuan Mahasiswa dalam Mengembangkan Perangkat Pembelajaran pada Pembelajaran Sains SD dengan Menggunakan Pendekatan PAKEM. Buletin Sibermas Vol 1 No. 5 hal. 90-105. 